\title{
Detection of huanglongbing of citruses (Citrus sp.) through Sentinel-2 satellite images in Huimanguillo, Tabasco, Mexico
}

\author{
Yzquierdo-Alvarez, Marilyn Estefania ${ }^{1}$; Ortiz-García, Garlos Fredy ${ }^{1}$; \\ Rincón-Ramírez, Joaquín Alberto ${ }^{*}$ \\ ${ }^{1}$ Colegio de Postgraduados, Campus Tabasco. Periférico Carlos A. Molina, Km 3.5. Carretera Cárdenas- \\ Huimanguillo. H. Cárdenas, Tabasco, Mexico C.P. 86500. \\ * Correspondence: jrincon@colpos.mx
}

Gitation: Yzquierdo-Alvarez, M. E., Ortiz-García, C. F., \&RincónRamírez, J. A. (2021). Detection of huanglongbing of citruses (Citrus sp. through Sentinel-2satellite images in Huimanguillo, Tabasco, Mexico. Agro Productividad. https://doi.org/10.32854 agrop.v14il2.2053

Editor in Chief: Dr. Jorge Cadena Iñiguez

Received: June 11, 2021.

Accepted: December 14, 2021

Published on-line: December 30 , 2021

Agro Productividad, 14(12). December. 2021. pp: 119-126.

This work is licensed under a Creative Commons Attribution-NonCommercial 4.0 International license.

\begin{abstract}
Objective: Develop a fast, practical, and inexpensive methodology for determining plants with HLB symptoms by exploring the potential use of Sentinel-2 satellite images.

Design/Methodology/Approach: Sentinel-2 images were used to perform a supervised classification to discriminate healthy Persian lime trees and trees with HLB molecularly verified by qPCR, and other land uses in the citrus growing area of Huimanguillo, Tabasco.

Results: The results showed that in the green $(560 \mathrm{~nm})$, red $(665 \mathrm{~nm})$, and near-infrared $(705 \mathrm{~nm})$ band regions, the spectral response of trees with HLB is higher than that of healthy trees. Likewise, there is an area of 26.96 and 12981 hectares of Persian lime affected and free of HLB, respectively, with an accuracy of $0.84 \%$ and a Kappa coefficient of 0.83 . Field verification corroborated three plantations where plants with HLB were previously detected and are currently in production.

Study Limitations/Implications: The study was carried out in the season of less cloud cover, as this is a limiting factor for the image analysis since it can lead to inadequate tracking of the affected area.

Findings/Conclusions: The results showed that it is possible to differentiate Persian lime plants affected by HLB from healthy plants using Sentinel-2 satellite images.
\end{abstract}

Keywords: Citrus greening, Candidatus Liberibacter asiaticus, satellite image, spectral reflectance.

\section{INTRODUCTION}

According to data from the Servicio de Información Agroalimentaria y Pesquera, in 2020 the surface cultivated of citrus in Mexico was approximately 572017 hectares, which generated an estimated production of 8017277 tons of fresh fruit. Of this cultivated surface, $58 \%$ is occupied by the orange, $21 \%$ by Persian lime, $17 \%$ by Mexican lime, and $4 \%$ by grapefruit and pomelo. In the state of Tabasco, there is a cultivated surface of 15 501 hectares of citrus, of which 94\% are established in the municipality of Huimanguillo, with 14189 ha of Persian lime and 438.5 ha of Valencia orange, contributing a production of 171966 tons of fresh fruit (SIAP, 2020); however, there are adverse factors such as pests and diseases that reduce their quality and production. Globally one of the most critical 
diseases today is citrus huanglongbing (HLB), considered one of the limiting factors in production since it reduces it in most cultivated areas, million citrus plants have been infected, and the yield has decreased (Bové, 2006). In the case of Mexico, HLB is caused by the bacteria Candidatus Liberibacter asiaticus (CLas), restricted to the plant's phloem; the bacteria is transmitted by the Asian citrus psyllidae, Diaphorina citri. In México, the first detection of CLas was carried out in 2009 in Yucatán (Trujillo-Arriaga, 2009), and in 2012 it was reported in Tabasco (Trujillo-Arriaga, 2012) after having been reported in other states of the north and south of the country. Currently, CLas and D. citri are distributed in all the citrus zones of the country. The productive losses that have been reported due to this disease have been $62 \%$ in Mexican lime (Robles-González et al., 2013) and 17\% in Persian lime (Flores-Sánchez et al., 2015). The characteristic symptom is a spotting of irregular and asymmetrical edge with regards to the central nerving of the leaves. In some cases, in the tree affected, there are yellow outbreaks with a sectoral distribution (Halbert and Manjunath, 2004; Gottwald et al., 2007). Once a tree branch is infected, the bacteria propagate gradually on the entire tree. The timely detection and elimination of sick trees are recommended to avoid the dispersion of HLB and monitor the plantations affected and control the vector insect (Keremane et al., 2015). The visual inspection of the trees by trained personnel is one of the most frequently used ways of detecting trees with HLB symptoms (Keremane et al., 2015); however, presently the most efficient method for the detection and confirmation of HLB is based on molecular detections through the use of the Polymerase Chain Reaction test in real-time (qPCR) (Hansen et al., 2008). However, both activities require a high investment of economic resources. In this sense, remote sensing emerges as a valuable and inexpensive tool for detecting different biological characteristics of the crops since data from the crops can be compiled quickly and analyzed in real-time. Recently the use of Sentinel-2 satellite images has proven to be efficient for the identification of damage in crops provoked by different pathogens, such as the corn streak virus (Dhau et al., 2019), where it was found that the maize infected was highly separable from the healthy maize and other classes of land-coverage with a general accuracy of 85.29\%. Caasi et al. (2020) evaluated the use of an economical method to detect damage from a bacterial blight on rice leaves and found that the sensors of the Sentinel-2 satellites have the potential of detecting and estimating the damages caused by the bacterial rice blight; likewise, Liu et al. (2020) implemented a spectral index based on the infrared region to detect the blight caused by Fusarium in wheat, and the general accuracy obtained was $78.6 \%$. Therefore, once the possible areas affected are detected, the producers can apply the necessary measurements in those zones without the need to inspect the entire cultivated surface. Thus, this study aimed to explore the potential use of Sentinel-2 satellite images to identify Persian lime trees with HLB symptoms and differentiate them from healthy trees in the citrus zone of Huimanguillo, Tabasco.

\section{MATERIALS AND METHODS}

The study area includes the citrus zone in the municipality of Huimanguillo, Tabasco (Figure 1). It is located between the extreme geographic coordinates: $17.95^{\circ}$ and $17.57^{\circ}$ latitude north, and $-93.43^{\circ}$ and $-93.76^{\circ}$ longitude west. 


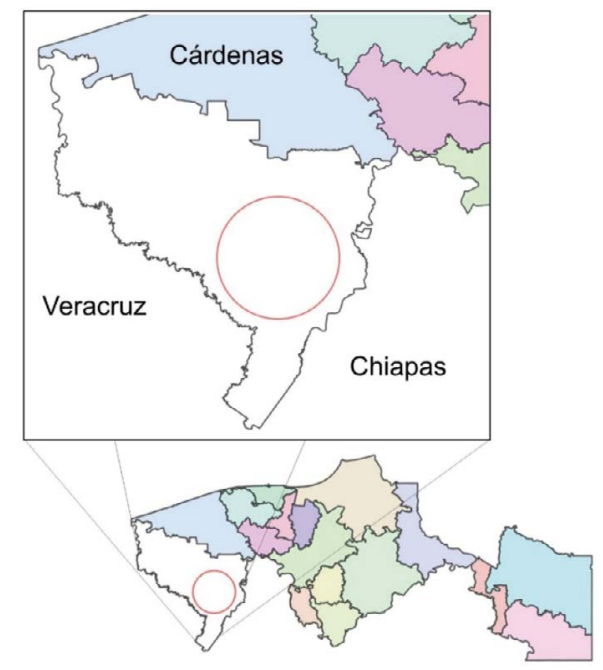

Figure 1. Study area, citrus zone of Huimanguillo, Tabasco.

\section{Field sampling and data obtaining}

Field sampling was conducted in two Persian lime plantations (PL) of 25 and 17 hectares, respectively (identified as plantation 1 and 2), which had an official report of cases of positive plants to CLas through the qPCR test, performed as part of the activities of the phytosanitary program against regulated citrus pests by the Plant Health State Committee (Comité Estatal de Sanidad Vegetal de Tabasco, CESVETAB). For the observation of symptoms, sampling was directed at plants with positive detections for the verification and georeferencing of each of the plants positive to CLas.

\section{Image acquisition}

Sentinel-2 satellite images, which have a resolution of $10 \mathrm{~m}$, were obtained for free from the USGS Global Visualization Viewer (GloVis) page, with the date March 26, 2020. The images were downloaded as compressed GeoTiff files, with UTM projection zone 15 and datum WGS84, and later they were integrated into a geographic information system managed with Quantum GIS (QGIS) version 3.16. Based on the polygons from the citrus plantations present in the zone, which are available in the CESVETAB database, the delimitation of the citrus zone was carried out to cut the images and adjust them to the study area. Later, for the following processes, the Semi-Automatic Classification Plugin (SCP) complement was used, which is a plugin for QGIS that allows the semi-automatic classification of remote sensing images (Congedo, 2020). The atmospheric correction was done using the automatic algorithm of the complement and the union of the 13 bands in a single virtual image to ease manipulating the information and maintain the most significant amount of helpful information.

To carry out the classification, a combination of 4-3-2 bands with natural color was used, with which the creation of samples or training sites was done, taking as reference the previous knowledge from the zone, to discriminate PL trees with HLB from healthy PL trees and the other coverages in the zone. For each type of coverage, 10 training areas 
were selected, and a supervised classification was made through the minimal distance algorithm.

For the validation of the classification, field verification was made of the plantations with possible HLB, healthy plants, plantations different from the training areas, and the polygons of citrus plantations were used as support. For the verification of the classification, r.kappa algorithm was used to calculate the kappa coefficient to evaluate the accuracy of the classification result. Values $>0.80$ represent a strong agreement or accuracy between the classification map and the terrain's reference information; values between 0.40 and 0.80 represent moderate agreement; and values $<0.40$ represent scarce agreement (Jensen, 2015).

\section{RESULTS AND DISCUSSION}

Based on spectral signatures obtained from the satellite image through the supervised classification, eleven classes were generated: PL plantations of less than five years and six years or more with possible HLB; PL plantations of three years or less; PL of five, eight, and fifteen years. These classes were created because, in the citrus zone, there are plantations with patches of different ages due to sowing and re-sowing of replacement seedlings. Likewise, or alternatively, there are plantations combined with other crops; however, in the classification, plants of less than 5 years of age were grouped as PL1 with HLB and plants of 6 years or more as PL2 with HLB; healthy PL of ages: less than 5 years, 5 to 10 years, and more than 10 years. The other classes of land coverage identified included grasslands, secondary vegetation, bodies of water, bare soil, and urban areas (Figure 2).

Similarly, the surface occupied by each of the classes was calculated: PL1 with HLB of less than five years, 24.44 ha; PL2 with HLB older than six years, 2.52 ha; PL less than five years, 6086.68 ha; PL of five to ten years, 4848.49 ha; PL older than ten years, 2045.95 ha. In total, the surface obtained was 26.96 hectares of PL affected by HLB and a surface of 12981 ha free of HLB, which in total integrated a surface of 13008 ha, indicating an incidence of HLB of $0.2 \%$, which is considered a low incidence with regards to the total of the surface cultivated in the zone. Regarding the plantations with official positive detections, the incidence found through the classification is between 4.6 and $12 \%$ in plantations 1 and 2 , respectively.

Figure 3 shows the spectral signatures of the PL trees with HLB and the healthy trees. It can be seen that in the regions of the green $(560 \mathrm{~nm})$, red $(665 \mathrm{~nm})$, and near-infrared band (VNIR) $(705 \mathrm{~nm}$ ), the spectral response of the sick trees is higher than those of the healthy trees.

This result agrees with what was found by Mishra et al. (2009), who studied the spectral characteristics of the leaves infected with HLB in visible and near-infrared regions, they found that the green $(530-595 \mathrm{~nm})$ and red $(710-750 \mathrm{~nm})$ bands in the visible region have an excellent potential to discriminate HLB. Similarly, Mishra et al. (2011) used the visible bands at $570 \mathrm{~nm}$ and $670 \mathrm{~nm}$ in a multispectral sensor in drones to detect the citrus trees infected with HBL in field conditions and achieve accuracy higher than 95\% in the classification. 

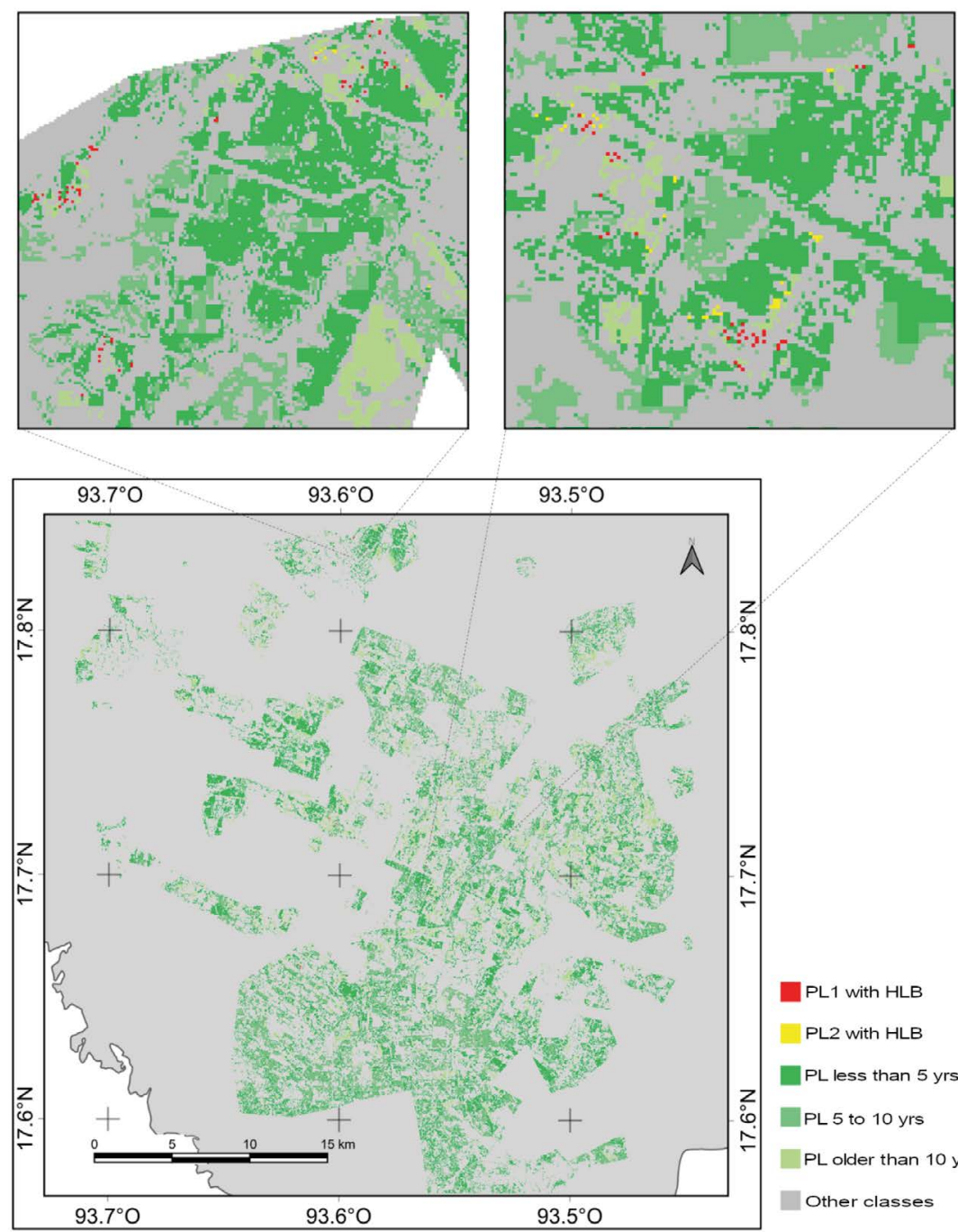

PL1 with HLB

PL2 with HLB

PL less than 5 yrs

PL 5 to 10 yrs

PL older than $10 \mathrm{yr}$

Other classes

Figure 2. Image classified from the citrus zone in Huimanguillo, Tabasco 2020. The zones with healthy Persian lime and with HLB are represented.

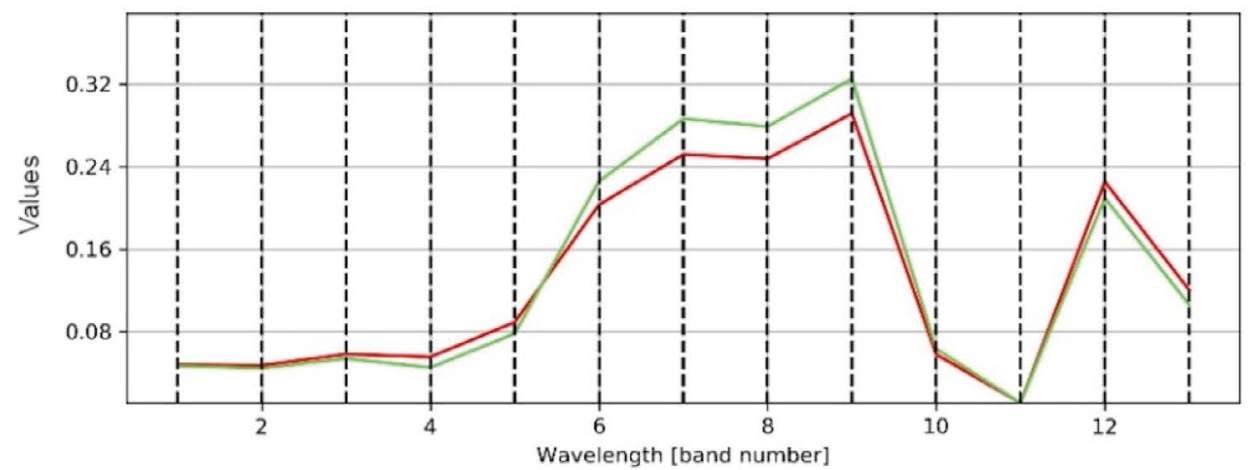

Figure 3. Spectral signatures of trees with HLB in red and healthy trees in green. 
In the field validation, it was found that there are six plantations with HLB symptoms, of which three already had detections through qPCR for HLB and which currently still maintain production; however, the highest amount of plants affected were found in the central and northwest part of the citrus-producing zone with an incidence of up to $12 \%$ in one of the plantations visited, which is why it is imperative to emphasize that zone with the purpose of limiting greater infection, taking into account that Yzquierdo-Alvarez et al. (2021) reported that the space-time fluctuations of $D$. citri in such a zone presents high populations, increasing the risk of dispersion towards neighboring plantations.

The sampled positive plantations detected presented plants with typical visual symptoms caused by HLB (Flores-Sánchez, 2015). These results indicate that it is possible to differentiate the PL plants spectrally with HLB from healthy plants using Sentinel-2 satellite images since the canopy of the trees sick with HLP has higher reflectance in the visible range than the canopy of the healthy trees (Sankaran $e t$ al., 2013).

In the classification performed, there was an accuracy of $0.84 \%$ and Kappa coefficient of 0.83 , indicating a strong classification (Jensen, 2015). The accuracy found in this study is higher than that reported by $\mathrm{Li}$ et al. (2015), where the differentiation of HLB was conducted through satellite images, WorldView-2 to monitor HLB quickly in large citrus plantations and to evaluate the capacity for HLB detection, and they obtained an accuracy of $81 \%$ and Kappa coefficient of 0.464 , a value lower than that found in our classification. Likewise, Sankaran and Ehsani (2011) found that HLB was detected in citrus leaves with a classification accuracy of the average sick class of approximately 75 to $84 \%$, which corroborates that using Sentinel-2 images can be a helpful tool for the timely detection of plants with HLB symptoms in extensive areas.

Adopting the methodology resulting from this study optimizes the search for trees with HLB symptoms by requiring a lower investment of personnel, time, and economic resources in comparison to the conventional visual inspection, at the same time that this increases the accuracy of detection, since in order to identify a tree infected with HLB through visual inspection the accuracy is between $47 \%$ and $59 \%$ (Futch et al., 2009).

It should be mentioned that in this study, the nutritional state of the trees was not contemplated, nor the period of symptom observation time, the management to which the plantations are subjected, the phenology of the crop, or the environmental factors, which is why these factors could be of use in a future classification and possibly improve the results found here.

\section{GONGLUSIONS}

The classification performed differentiates Persian lime trees with HLB from healthy trees with an accuracy of $0.84 \%$, which is why using Sentinel-2 satellite images can be used as a useful tool for the timely detection of plants with HLB symptoms and to streamline plant health intervention processes to minimize the regional dispersion of HLB.

\section{ACKNOWLEDGEMENTS}

We thank the State Committee for Plant Health in Tabasco for the information and support to conduct this research. 


\section{REFERENGES}

Caasi, O., Hongo, C., Wiyono, S., Giamerti, Y., Saito, D., Homma, K., and Shishido, M. (2020). The potential of using Sentinel-2 satellite imagery in assessing bacterial leaf blight on rice in West Java, Indonesia. Journal of International Society for Southeast Asian Agricultural Sciences 26, 1-16.

Congedo, L. (2020). Semi-Automatic Classification Plugin Documentation. doi: 10.13140/ RG.2.2.25480.65286/1

Bové J. M. (2006). Huanglongbing: a destructive, newly-emerging, century-old disease of citrus. Journal of Plant Pathology 88, 7-37.

Dhau, I., Dube, T., and Mushore, T. D. (2019). Examining the prospects of sentinel-2 multispectral data in detecting and mapping maize streak virus severity in smallholder Ofcolaco farms, South Africa. Geocarto International 1-11. DOI: https://doi.org/10.1080/10106049.2019.1669724

Flores-Sánchez, J. L., Mora-Aguilera, G., Loeza-Kuk, E., López-Arroyo, J. I., Domínguez-Monge, S., AcevedoSánchez, G., y P. Robles-García. (2015). Pérdidas en producción inducidas por Candidatus Liberibacter asiaticus en limón persa, en Yucatán México. Revista mexicana de fitopatología 33(2), 195-210.

Futch, S., Weingarten, S., and Irey, M. (2009). Determining HLB infection levels using multiple survey methods in Florida citrus. Proceedings Florida State Horticultural Society 122(1), 152-158.

Gottwald, T. R., Graça, J. V. D., and Bassanezi R. B. (2007). Citrus huanglongbing: the pathogen and its impact. Plant Health Progress 8, 31. DOI: https://doi.org/10.1094/PHP-2007-0906-01-RV

Halbert, S. E. and K. L. Manjunath. (2004). Asian citrus psyllids (Sternorrhyncha: Psyllidae) and greening disease of citrus: a literature review and assessment of risk in Florida. Florida Entomologist 87, 330-353. DOI: https://doi.org/10.1653/0015-4040(2004)087[0330:ACPSPA]2.0.CO;2

Hansen, A. K., Trumble, J. T., Stouthamer, R., and Paine, T. D. (2008). A new huanglongbing species, "Candidatus Liberibacter psyllaurous," found to infect tomato and potato, is vectored by the psyllid Bactericera cockerelli (Sulc). Applied and environmental microbiology 74(18), 5862-5865. DOI: 10.1128/ AEM.01268-08

Jensen J.R. (2015). Introductory digital image processing: a remote sensing perspective, remote sensing-derived thematic map accuracy assessment (pp. 557-582). Pearson series in geographic information science.

Keremane, M. L., Ramadugu, C., Rodriguez, E., Kubota, R., Shibata, S., Hall, D. G., and Lee, R. F. (2015). A rapid field detection system for citrus huanglongbing associated 'Candidatus Liberibacter asiaticus' from the psyllid vector, Diaphorina citri Kuwayama and its implications in disease management. Crop Protection 68, 41-48. DOI: https://doi.org/10.1016/j.cropro.2014.10.026

Li, X., Lee, W. S., Li, M., Ehsani, R., Mishra, A. R., Yang, C., and Mangan, R. L. (2015). Feasibility study on Huanglongbing (citrus greening) detection based on WorldView-2 satellite imagery. Biosystems engineering 132, 28-38. DOI: https://doi.org/10.1016/j.biosystemseng.2015.01.009

Liu, L., Dong, Y., Huang, W., Du, X., Ren, B., Huang, L., and Ma, H. (2020). A Disease Index for Efficiently Detecting Wheat Fusarium Head Blight Using Sentinel-2 Multispectral Imagery. IEEE Access, 8, 52181-52191. DOI: 10.1109/ACCESS.2020.2980310

Mishra, A. R., Ehsani, R. E. Z. A., Karimi, D., and Albrigo, L. G. (2009). Potential applications of multiband spectroscopy and hyperspectral imaging for detecting HLB infected orange trees. Proceedings of the Florida State Horticultural Society 122, 147-151.

Mishra, A., Karimi, D., Ehsani, R., and Albrigo, L. G. (2011). Evaluation of an active optical sensor for detection of Huanglongbing (HLB) disease. Biosystems engineering 110(3), 302-309. DOI: https://doi. org/10.1016/j.biosystemseng.2011.09.003

Robles-González, M. M., Velázquez-Monreal.J.J., Manzanilla-Ramírez. M. A., Orozco-Santos. M., MedinaUrrutia. V. M., López-Arroyo, J. I., y Flores-Virgen R. (2013). Síntomas del Huanglongbing (HLB) en limón mexicano (Citrus aurantifolia) y su dispersión en el estado de Colima, México. Revista Chapingo Serie Horticultura 19(1), 15-31. doi: https://doi.org/10.5154/r.rchsh.2012.01.005

Sankaran, S., Maja, J. M., Buchanon, S., and Ehsani, R. (2013). Huanglongbing (Citrus Greening) Detection Using Visible, Near-Infrared and Thermal Imaging Techniques. Sensors 13, 2117-2130. DOI: https:// doi.org/10.3390/s130202117

Sankaran, S., Mishra, A., Maja, J. M., and Ehsani, R. (2011). Visible-near infrared spectroscopy for detection of huanglongbing in citrus orchards. Computers and electronics in agriculture 77(2), 127-134. DOI: https:// doi.org/10.1016/j.compag.2011.03.004

SIAP. (2020). Avance de Siembras y Cosechas. Servicio de Información Agroalimentaria y Pesquera. Recuperado de: http://infosiap.siap.gob.mx:8080/agricola_siap_gobmx/ResumenProducto.do

Trujillo-Arriaga, J. (2009). Servicio Nacional de Sanidad, Inocuidad y Calidad Agroalimentaria. Dirección General de Sanidad Vegetal. Oficio B00.01,01,01.03.-10791. Circular No. 120. Zona bajo control fitosanitario. 22 de septiembre de 2009. Recuperado de: https:/www.gob.mx/cms/uploads/attachment/ 
file/346556/120-_Se_declara_como_ZBCF_Yucatan_y_Q__Roo_por_HLB_y_su_vector_el_Psilido_ asiatico.pdf (consultado 22 de junio de 2020).

Trujillo-Arriaga, J. 2012. Servicio Nacional de Sanidad, Inocuidad y Calidad Agroalimentaria. Dirección General de Sanidad Vegetal. Oficio B00.01,02,01,01./. -12767. Aviso No. 189. Zona bajo control fitosanitario. 13 de diciembre de 2012. Recuperado de: https://www.gob.mx/cms/uploads/attachment/ file/346568/12767_AVISO_189._TABASCO_ZONA_BAJO_CONTROL_FITOSANITARIO_ HLB.pdf (consultado 22 de junio de 2020).

USGS. (2020). United States Geological Survey. Earth Explorer Platform. Recuperado de: https://www.usgs. gov/

Yzquierdo-Alvarez, M. E., Rincón-Ramírez, J. A., Loeza-Kuk, E., López-Olguín, J. F., Aceves-Navarro, L. A., Ortiz-García, C. F. (2021) Fluctuación espacio-temporal de Diaphorina citri Kuwayama (Hemiptera: Liviidae) en limón Persa (Citrus latifolia) en la zona citrícola de Huimanguillo, Tabasco. Acta Zoológica Mexicana (nueva serie) 37, 1-14. doi: 10.21829/azm.2021.3712374 elocation-id: e3712374 